\title{
KONSEP MANAJEMEN SUMBER DAYA MANUSIA DALAM KELEMBAGAAN ISLAM
}

\author{
Sri Rokhmiyati \\ Dosen Manajemen Dakwah IAIN Salatiga \\ rohmyabieta.79@gmail.com
}

\begin{abstract}
Management could be defined as the art for organizing matters and the way for managing institution, agency, work or community who involve in it, this aims to accommodate the work conducted. Human Resources have become part of the strategic planning process and part of developing organizational policy, design for the expansion of organizational lines, merger process and organizational acquisition. The importance of human resource management and their role in Islamic Institutions, it is depending on the management, if it is not organized well, the development of Islamic Institutions will face challenges due to managerial weakness. The implementation of Islamic Institutional management comprehensively will develop the quality of the institutions, including Islamic schools, madrasah and Islamic boarding schools. The human resource continues to grow in all existing institutions. Thus, the effort to develop a successful institution depends on the significant changes in human resource management.
\end{abstract}

Keywords: human resource management, islamic institution

\begin{abstract}
Abstrak
Manajemen merupakan suatu seni untuk mengatur sesuatu dan salah satu cara untuk mengelola suatu lembaga, instansi, pekerjaan ataupun orang orang yang berada didalamnya, dengan tujuan mempermudah pekerjaan yang di laksanakan. Sumber Daya Manusia yaitu bagian proses perencanaan strategis dan menjadi bagian pengembangan kebijaksanaan organisasi, perencanaan perluasan lini organisasi, proses marger dan akuisisi organisasi. Pentingnya manajemen sumber daya manusia dan fungsi sumber daya manusia dalam Kelembagaan Islam, hal tersebut dikarenakan jika manajemennya tidak tertata dengan baik, maka perkembangan Kelembagaan Islam akan mengalami hambatan yang datang karena lemahnya manajerial. Implementasi manajemen Kelembagaan Islam secara komprehensif akan mampu meningkatkan mutu di lembaga tersebut, baik sekolah Islam, madrasah maupun pondok pesantren. Sumber Daya Manusia terus berkembang pada seluruh lembaga yang ada saat ini. Segala upaya yang diperlukan untuk menciptakan suatu lembaga yang berhasil tergantung pada perubahan yang signifikandalam Manajemen Sumber Daya Manusia.
\end{abstract}

Kata kunci: manajemen sumber daya manusia, kelembagaan Islam 


\section{Pendahuluan}

Manajemen pada dasarnya membutuhkan interaksi dan sinergitas antar komponen organisasi dengan menggerakan sumber daya manusia yang dimiliki, yang bertujuan untuk mewujudkan harapan dan citacita organisasi atau kelembagaan. Ditinjau dari suatu ilmu, manajemen memiliki objek studi, pendekatan dan strategi, metode sehingga dapat digunakan dan diterapkan dalam masyarakat. Dengan demikian manajemen memiliki keterkaitan dengan berbagai disiplin ilmu lainnya, sehingga memungkinkan manajemen dapat dipelajari, diteliti, dianalisis dan dikembangkan sebagai ilmu terapan dalam mengelola suatu organisasi atau lembaga. Sebagai suatu proses manajemen membutuhkan desain dan strategi yang didalamnya ada ide dan gagasan dasar lambaga yang akan dicapai melalui proses manajemen.

Sebuah kelembagaan Islam harus menjamin mutu untuk manjaga eksistensinya di tengah kompetisi yang sekarang ini semakin ketat. Selain itu harus mempunyai kemampuan dalam mendayagunakan sumbersumber pendidikan dalam lembaga untuk meningkatkan kemampuan belajar secara optimal (Tilaar:1993:159). Untuk meningkatkan mutu kelembagaan Islam baik sekolah Islam, madrasah, ataupun pesantren, maka seorang pemimpin harus menyadari pentingnya visi, misi, tujuan dan sasaran yang akan dicapai, agar proses yang dilakukan lembaga tersebut akan mempunyai arah yang di inginkan tidak hanya proses yang berlangsung sebagai rutinitas tanpa arah dan tujuan yang jelas.

Masyarakat muslim memiliki ekspektasi yang sangat besar terhadap keberhasilan dan kemajuan kelembagaan Islam. Namun ekspektasi itu belum terealisasi sepenuhnya sampai sekarang. Hingga kini masih ada persepsi didalam masyarakat tentang citra kelembagaan Islam sebagai lembaga "seccon class". Maka dari itu, masyarakat muslim harus merespon dengan melakukan perbaikan dan pembenahan dalam strategi manajerialnya. Melalui kelembagaan Islam dapat melakukan 
proses pengambilan keputusan yang berada pada sistem pengelolaan, kepemimpinan, peningkatan mutu dan effective schools.

Secara sosiologis, kelembagaan Islam berperan menyiapkan generasi muda untuk hidup dalam masyarakat setelah dewasa tanpa kesulitan, baik secara sosial-keagamaan, politik, ekonomi, dan budaya (Sudarjito, 2003:119). Lembaga menjadi salah satu faktor penentu dalam mengatasi segala masalah dan ketegangan yang dihadapi masyarakat, baik ketegangan yang bersifat individual, maupun ketegangan-ketegangan sosial. kelembagaan Islam harus menjadi tempat bagi masyarakat untuk belajar menghormati hak-hak orang lain, atau kelompok lain. Menggunakan kemajuan pengetahuan untuk melestarikan perkembangan manusia daripada menciptakan perbedaan yang lebih besar antara sesama manusia, yang bermuara pada terciptanya konflik (Delors, t.th:11).

Menurut pendapat para peneliti dan teoretisi, aset Sumber Daya Manusia dapat menjadi sumber keunggulan kompetitif yang berkelajutan karena aset-aset manusia tersebut mempunyai pengetahuan dan kompleksitas sosial yang sulit ditiru oleh para pesaing. SDM merupakan asset kritis organisasi yang tidak hanya diikutsertakan dalam filosofi kelembagaan tetapi juga dalam proses perencanaan strategis. Menurut Kathrin Connor (dikutip dari Schuller, 1990), wakil presiden SDM di Liz Claiborne menyatakan bahwa:

Human resources are a part of the strategic planning process. It is a part of policy development, line extension planning and the merger and acquisition processes. Little is done in planning policy on the finalization stages of any deal.

Pernyataan Kathrin Connor, diakui bahwa hanya sebagian kecil saja hal-hal yang dilakukan organisasi tanpa melibatkan sumber daya manusia dalam membuat perencanaan, kebijaksanaan, dan pembentukan strategi organisasi. Apabila organisasi melakukan perencanaan strategis, manajer lebih berkemungkinan melihat sifat-sifat penting isu-isu Sumber Daya Manusia yang ada. Masalah-masalah Sumber Daya Manusia terus 
meningkat khususnya berkenaan dengan semakin sengitnya persaingan yang terjadi dan perubahan lingkungan global, organisasi dan dunia kerja juga mengalami perubahan. Isu-isu yang berkaitan dengan Sumber Daya Manusia terus berkembang dan menyebar pada seluruh organisasi yang ada saat ini.

\section{Konsep Manajemen Sumber Daya Manusia}

Manajemen merupakan salah satu sains yang diperlukan dalam mengarahkan perubahan di masa depan dalam kehidupan suatu bangsa. Manajemen menjadi alat untuk mencapai tujuan organisasi melalui pemanfaatan sumber daya yang ada dalam organisasi. Keunggulan manajemen justru terletak pada sumber daya manusia yang profesional yang diharapkan akan dapat menggunakan manajemen dalam mengefektifkan perubahan bagi kepentingan hidup di masa depan. Hal ini sejalan dengan paradigma baru pendidikan Nasional yang mengacu pada pengelolaan kelembagaan oleh Sumber Daya Manusia yang profesional, yang menjadi satu pilar utama keberhasilan organisasi pendidikan menghasilkan sumber daya yang bermutu.

Manajemen berasal dari bahasa latin, yaitu berasal dari kata manus yang berarti tangan, dan agere artinya melakukan; digabung menjadi kata kerja managere, yang artinya menangani; diterjemahkan ke dalam bahasa inggris, to manage, kata bendanya managemet (mengatur atau mengelola); manajemen kini diartikan pengelolaan (Usman, 2008:4). Menurut arti istilah, banyak pakar yang mengemukakan beragam definisi: (1) manajemen adalah ilmu dan seni perencanaan, pengorganisasian, penyusunan, pengarahan dan pengawasan sumber daya untuk mencapai tujuan yang sudah ditetapkan, (2) manajemen yaitu segenap proses penyelenggaraan dalam setiap usaha kerjasama sekelompok manusia untuk mencapai tujuan tertentu, (3) sejumlah pakar mengartikan: manajemen adalah pencapaian tujuan yang ditetapkan lebih dulu dengan mempergunakan 
kegiatan orang lain (Stoner J.A.F, 2000:5). Malayu S.P.Hasibuan (2001:2) berpendapat bahwa manajemen merupakan ilmu, seni yang mengatur proses pemanfaatan sumber daya manusia beserta sumber-sumber lainnya secara efektif dan efisien untuk mencapai suatu tujuan tertentu.

Adapun Stoner sebagaimana dikutip oleh Handoko (2003:8) juga mengemukakan bahwa manajemen merupakan proses perencanaan, pengorganisasian, pengarahan dan pengawasan terhadap kegiatan yang dilakukan oleh para anggota organisasi dan penggunaan sumber daya organisasi lainnya agar mencapai tujuan yang telah ditetapkan.

Dalam proses manajemen terlibat beberapa komponen pokok yang ditampilkan oleh seorang pimpinan, yaitu; perencanaan (Planning), pengorganisasian (Organizing), pemimpinan (Leading), dan pengawasan (Controlling). Sedangkan menurut Usman (2010:15) Fungsi manajemen meliputi; perencanaan, pengorganisasian, pengarahan dan pengendalian. Oleh sebab itu, manajemen diartikan sebagai proses merencanakan, mengorganisasi, memimpin, dan mengendalikan upaya organisasi dengan segala aspeknya agar tujuan organisasi tercapai secara efektif dan efisien. Manullang (2008:4) berpendapat bahwa dalam manajemen terdapat unsur perencanaan, pembuatan keputusan, pengorganisasian, dan penyempurnaan. Sedangkan menurut Ngalim Purwanto (2010:14) meliputi; perencanaan, organisasi, koordinasi, komunikasi, supervisi kepengawasan-pembiayaan dan evaluasi.

Berbagai pendapat tersebut, pada hakikatnya dikembalikan kepada empat bagian, yang dijabarkan sebagai berikut; perencanaan (planning: budgeting, programming, decision making, forcasting, pengorganisasian (organizing): structuring, assembling resources, staffing, penggerakan (actuating): coordinating, directing, commanding. Kerangka keilmuan menejemen memegang peranan penting dalam menyempurnakan fungsi menejemen terutama dalam menjalankan dan upaya mengembangkan kelembagaan Islam yang unggul. Maka dari pada itu keberadaannya dapat menjadi 
rujukan dan implementasi pengembangan lembaga Islam di era otonomi seperti saat ini.

Pengembangan SDM dalam organisasi merupakan bentuk usaha pengembangan yang bersifat integral, baik yang menyangkut SDM sebagai sistem dan sebagai individu, maupun organisasi sebagai wadah SDM untuk memenuhi kebutuhan suatu organisasi manapun. Dalam pengembangan SDM ini tentu dilakukan secara terencana dan berkesinambungan untuk meningkatkan kempetensi kinerja organisasi dan pegawai melalui program pendidikan, pelatihan dan pengembangan.

Konsep SDM diberi kesempatan mengambil peran penting dalam tim manajemen. Hal ini terjadi karena fungsi sumber daya manusia sedang berubah menjadi fungsi manajemen yang penting. Segala upaya yang diperlukan untuk menciptakan suatu organisasi yang berhasil tergantung pada perubahan yang signifikan dalam Manajemen SDM. Berbagai upaya yang dilakukan organisasi adalah: (1) Perampingan organisasi (downsizing) yang meliputi suksesi manajemen, pemberian uang pesangon, pensiun, dan program-program perencanaan SDM yang lebih baik untuk mengurangi terjadinya downsizing lebih lanjut. (2) Desentralisasi melibatkan upaya melatih pekerja dalam penilaian kerja, perubahan-perubahan kompensasi, pembuatan keputusan, dan ketrampilan-ketrampilan kepemimpinan (leadership) yang baru.

Berdasarkan pengalaman-pengalaman eksekutif tidak ada organisasi yang fleksibel, yang ada hanya orang-orang yang fleksibel. Sumber Daya Manusia diharapkan dapat mengarahkan dan mendukung upaya organisasi untuk mengembangkan kemampuan manajer dalam sebuah organisasi yang lebih ramping, datar, dan fleksibel. Pengelolaan SDM dituntut lebih proaktif dan responsif, segala aktivitas yang dilakukan harus dapat mengantisipasi berbagai perkembangan yang terjadi, kemudian melakukan tindakan-tindakan untuk mengahadapi isu-isu yang berkaitan dengan SDM. Manajemen sumber daya manusia (MSDM) 
telah berubah dari fungsi spesialisasi yang berdiri sendiri menjadi fungsi yang terintegrasi dengan seluruh fungsi-fungsi lain dalam organisasi, untuk mencapai sasaran yang telah ditetapkan. Berubahnya fungsi dan pusat perhatian MSDM memerlukan perubahan kualifikasi pengelola MSDM agar dapat mengikuti perkembangan dan memberikan tanggapan yang sesuai. Sudah semestinya, perhitungan kelembagaan Islam saat ini ditujukan pada pengembangan pengelolaan SDM secara signifikan dan kontinyu. Pengembangan pengelolaan SDM harus memenuhi tuntutan perkembangan dan kebutuhan organisasi. Tidak bisa dipungkiri dengan semakin pesatnya perkembangan teknologi pengelolaan SDM diarahkan untuk mendukung jaringan yang lebih luas dan berkembang. Pada dasarnya bisa dikatakan bahwa untuk bertahan dalam persaingan maka pengelolaan SDM memberikan suatu peran strategis, dengan memastikan bahwa kompetensi dapat memenuhi tuntutan kinerja organisasi saat ini.

\section{Kelembagaan Islam}

Kelembagaan Islam sebagai sebagai wadah mempunyai peranan penting dalam upaya proses belajar mengajar antara pendidik dan peserta didik. Charles Michael Stanton (1994:25), menggolongkan lembaga pendidikan Islam ke dalam dua bentuk, yaitu "lembaga pendidikan formal yang mengajarkan pengetahuan agama, dan pendidikan nonformal yang mengajarkan pendidikan umum termasuk filsafat". George Makdisi (1992:16), dalam hal yang sama menyebutnya sebagai lembaga pendidikan eksklusif (tertutup) yang hanya mengajarkan pengetahuan agama, dan lembaga pendidikan inklusif (terbuka) yang mengajarkan pengetahuan umum.

Secara umum pendidikan Islam adalah ilmu pendidikan yang berdasarkan Islam, oleh sebab itu, pendidikan Islam harus bersumber kepada al-Quran dan hadis Nabi (Maksum, 1999:9) Islam adalah agama yang diperintahkan Allah SWT kepada manusia untuk memeluknya secara utuh dan menyeluruh. Ajaran Islam ini diperuntukan bagi 
manusia sebagai petunjuk ke jalan yang lurus ketika melaksanakan tugastugas hidup serta mencapai tujuan hidup di dunia ini. Dengan demikian ajaran Islam diciptakan oleh Allah SWT sesuai dengan proses penciptaan dan tujuan manusia di muka bumi ini. Namun manusia, dengan segala kekurangannya tidak akan menjalankan tuntutan agama Islam dengan baik tanpa mengerti, mengetahui dan memahami Islam secara mendalam dan menyeluruh. Untuk dapat mengetahui dan memahami Islam secara menyeluruh tersebut, maka tidak ada jalan kecuali melalui pendidikan. Karena, Islam dan pendidikan mempunyai "hubungan yang sangat erat". Hubungan ini digambarkan bahwa Islam sebagai tujuan dan pendidikan adalah alatnya (Aly, 1999:1).

Berdasarkan uraian di atas, dapat digaris bawahi bahwa Islam menempatkan pendidikan sebagai suatu kewajiban umat manusia dalam rangka memenuhi fitrahnya sebagai khalifah dimuka bumi, lebih-lebih jika dikaitkan dengan kekuatan akal dan pikiran yang dimiliki manusia (Hamdani Ali, 1993:90). Tanpa pendidikan, kekuatan tersebut akan menjadi bumerang bagi kehidupan manusia itu sendiri. Sesuai dengan fitrahnya, ilmu pengetahuan (pendidikan) diberikan Allah SWT kepada manusia untuk mengurus bumi itu. Disinilah letak esensinya, Allah SWT mewajibkan umat manusia untuk menempuh pendidikan.

Proses kependidikan Islam memerlukan konsep-konsep yang dapat dikembangkan menjadi teori-teori yang teruji dalam aplikasinya di lapangan. Bangunan teoritis kependidikan Islam akan dapat berdiri tegak di atas pondasi pandangan dasar (filosofi) yang telah digariskan oleh Allah dalam al-Quran. Apa yang terjadi sekarang adalah akibat logis dari perubahan sosial di belbagai sektor kehidupan umat manusia beserta nilai-nilainya yang juga ikut mengalami pergeseran telah memaksa pendidikan Islam harus merubah strategi dan metode operasionalnya. Perubahan strategi dan metode menuntut adanya perombakan model sampai dengan institusinya, sehingga lebih efektif dan efisien dalam arti 
pedagogis, sosiologis dan kultural (Arifin, 1995:2).

Pada dasarnya munculnya madrasah-madrasah di dunia Islam merupakan usaha pengembangan dan penyempurnaan kegiatan proses belajar mengajar dalam upaya untuk menampung pertumbuhan dan perkembangan ilmu pengetahuan, dengan jumlah pelajar yang semakin meningkat dan bertambah setiap tahun ajaran. Sementara itu, madrasah boleh dikatakan sebagai fenomena baru dari lembaga pendidikan Islam yang ada di Indonesia, yang kehadirannya sekitar permulaan abad ke-20. Namun dalam penyelenggaraan pendidikan dan pengajarannya masih belum punya keseragaman antara daerah yang satu dengan daerah yang lain, terutama sekali menyangkut kurikulum dan rencana pelajaran. Madrasah adalah ujung tombak terdepan dalam pelaksanaan proses pendidikan Islam. Madrasah sebagai lembaga pendidikan yang tumbuh dan berkembang dari tradisi pendidikan agama dalam masyarakat, memiliki arti penting sehingga keberadaannya terus diperjuangkan.

Madrasah adalah sekolah umum yang bercirikan Islam, pengertian ini menunjukan dari segi materi kurikulum, madrasah mengajarkan pengetahuan umum yang sama dengan sekolah-sekolah umum sederajat, hanya saja yang membedakan madrasah dengan sekolah umum adalah banyak pengetahuan agama yang diberikan, sebagai ciri khas Islam atau sebagai lembaga pendidikan yang berada di bawah naungan Departemen Agama.

Dengan demikian posisi madrasah tidak semata-mata dipahami sebagai lembaga pendidikan yang formal saja namun ada madrasah non formal pula, yaitu Madrasah Dinniyah. Dalam lembaga Islam Madrasah Dinniyah memiliki misi yang sangat strategis dalam membentuk santri yang religius, dan berakhlak Islami (Zulkarnain, 2008:31). Madrasah Dinniyah bukan hanya saja mengajarkan ilmu sebagai materi, atau keterampilan sebagai kegiatan, melainkan selalu mengaitkan semuanya dengan praktik (amaliah) yang bermuatan nilai dan moral, karena 
disinilah titik awal dari semua kegiatan proses belajar mengajar.

Madrasah sebagai lembaga pendidikan Islam di Indonesia relatif lebih muda dibanding pesantren. Dengan munculnya Madrasah Manba'ul Ulum Kerajaan Surakarta tahun 1905 dan Sekolah Adabiyah yang didirikan oleh Syekh Abdullah Ahmad di Sumatera Barat tahun 1909 (Malik Fadjar, 1998). Madrasah berdiri atas inisiatif dan realisasi dari pembaharuan sistem pendidikan Islam yang telah ada. Pembaharuan tersebut, menurut Karl Sternbrink (1986), meliputi tiga hal, yaitu: (1) Usaha menyempurmakan sistem pendidikan pesantren, (2) penyesuaian dengan sistem pendidikan Barat, dan (3) upaya menjembatani antara sistem pendidikan tradisional pesantren dan sistem pendidikan Barat.

Madrasah sebagai lembaga pendidikan Islam kini ditempatkan sebagai pendidikan sekolah dalam sistem pendidikan nasional. Munculnya SKB tiga menteri (Menteri Agama, Menteri Pendidikan dan Kebudayaan, dan Menteri dalam Negeri) menandakan bahwa eksistensi madrasah sudah cukup kuat beriringan dengan sekolah umum. Di samping itu, munculnya SKB tiga menteri tersebut juga dinilai sebagai langkah positif bagi peningkatan mutu madrasah baik dari status, nilai ijazah maupun kurikulumnya.

Sebagai upaya inovasi dalam Sistem kelembagaan Islam, madrasah tidak lepas dari berbagai problema yang dihadapi. Problemaproblema tersebut, menurut Darmu'in (1998), antara lain (1) Madrasah telah kehilangan akar sejarahnya, artinya keberadaan madrasah bukan merupakan kelanjutan pesantren, meskipun diakui bahwa pesantren merupakan bentuk lembaga pendidikan Islam pertama di Indonesia. (2) Terdapat dualisme pemaknaan terhadap madrasah. Di satu sisi, madrasah diidentikkan dengan sekolah karena memiliki muatan secara kurikulum yang relatif sama dengan sekolah umum. Di sisi lain, madrasah dianggap sebagai pesantren dengan sistem klasikal yang kemudian dikenal dengan madrasah Dinniyah. 
Dualisme pendidikan Islam juga muncul dalam bidang manajerialnya, khususnya di lembaga swasta. Lembaga swasta umumnya memiliki dua top manager yaitu kepala madrasah dan ketua yayasan atau pengurus. Meskipun telah ada garis kewenangan yang memisahkan kedua top manager tersebut, yakni kepala madrasah memegang kendali akademik sedangkan ketua yayasan atau pengurus membidangi penyediaan sarana dan prasarana, sering di dalam praktik terjadi overlapping. Masalah ini biasanya lebih buruk jika di antara pengurus yayasan tersebut ada yang menjadistaf pengajar. Disamping ada kesan memata-mataikepemimpinan kepala madrasah, juga ketika staf pengajar tersebut melakukan tindakan indisipliner (sering datang terlambat), kepala madrasah merasa tidak berdaya menegurnya.

Praktek manajemen di madrasah sering menunjukkan model manajemen tradisional, yakni model manajemen feodalistik atau paternalistik. Dominasi senioritas semacam ini terkadang mengganggu peningkatan dan perkembangan kualitas kelembagan. Munculnya kreativitas inovatif dari kalangan muda terkadang dipahami sebagai sikap yang tidak menghargai senior. Kondisi yang demikian ini mengarah pada ujung ekstrim negatif, hingga muncul kesana bahwa mengoreksi kekeliruan langkah senior atau meluruskan langkah dianggap tabiat su'ul adab.

Kesenjangan antara madrasah negeri dan madrasah swasta tampaknya juga menjadi masalah yang belum tuntas diselesaikan. Kesenjangan tersebut meliputi beberapa hal seperti pandangan guru, kualitas input siswa, sarana prasarana dan sebagainya yang kesemuanya itu berpengaruh baik langsung maupun tidak langsung kepada mutu pendidikan. Demikian ini karena munculnya SKB tiga menteri tersebut belum diimbangi penyediaan guru, buku-buku dan peralatan lain dari departemen terkait (Fadjar, 1998:1). 


\section{Peranan Kelembagaan Islam di Madrasah Ibtida'iyah dan Dinniyah}

Hakikat kelembagaan madrasah seiring dengan tujuan pendidikan melalui misi madrasah. Dalam rangka perwujudan hakikat tersebut sudah barang tentu memerlukan suatu perangkat operasional yang berkualitas yang selalu dikembangkan sesuai dengan kemajuan dan kebutuhan masyarakat, melalui peningkatan berbagai komponen seperti metodelogi dan pengembangan kurikulum, pemenuhan dan peningkatan mutu kemampuan tenaga pendidik, sarana prasarana dan lain-lain (Ahmadiansah, 2016:224).

Madrasah sebagai lembaga Pendidikan Islam harus senantiasa bertitik tolak dari rumusan diatas sehingga output dari lembaga ini mampu bersaing dengan lembaga pendidikan lain. Ada beberapa unsur pendidikan yang harus dipenuhi agar tujuan Madrasah bisa tercapai: (1) Bahwa pendidikan itu harus merupakan usaha sadar yang dilakukan oleh orang dewasa atau orang tua atau siapa saja yang bertanggung jawab dalam rangka mempersiapkan dan membimbing anak, dengan atas nama Allah SWT serta bertanggung jawab kepada-Nya. (2) Bahwa yang dibimbing dengan pendidikan itu adalah anak atau generasi dengan seluruh kelengkapan dasar potensi-potensi pembawaan fitrahnya, agar tumbuh berkembang secara bertahap dan berangsur-angsur kearah yang sempurna. (3) Tujuan pembimbingan dan pendidikan adalah agar anak nantinya mampu melaksanakan tugas-tugas hidup yaitu tugas kekhalifahan dengan penuh tanggung jawab kepada Allah SWT. (4) Karena pedomannya adalah al-Quran, baik secara konseptual maupun praktis, maka kurikulum, materi, metode, cara pelaksanaannya, evaluasi dan alat pendidikan lainnya, dapat dijabarkan dan dikembangkan dari al-Quran, mulai dari proses turunnya, penjelasan-penjelasan dari Nabi serta contoh-contoh yang telah diberikan oleh Nabi Muhammad SAW (Tadjab, 2000:58). 


\section{Kelembagaan Islam dan Pengembangan Madrasah}

Dalam upaya mencari "model alternatif Kelembagaan Islam" yang akan disesuaikan dengan kebutuhan masyarakat madani Indonesia, paling tidak ada tiga pendekatan yang ditawarkan sebagai pola alternatif Kelembagaan Islam, yaitu (1) pendekatan sistemik, yaitu perubahan harus dilakukan terhadap keseluruhan sistem pada lembaga Islam formal dan non formal yang ada, dalam arti terjadi perubahan total. (2) Pendekatan suplementer, yaitu dengan menambah sejumlah paket Lembaga Islam yang bertujuan memperluas pemahaman dan penghayatan ajaran Islam secara lebih memadai. Langkah ini yang sering dilakukan dengan istilah yang populer adalah "tambal sulam". (3) Pendekatan komplementer, yaitu dengan upaya mengubah kurikulum dengan sedikit radikal untuk disesuaikan secara terpadu (Suroyo, 1991:64). Artinya, untuk kondisi sekarang ini, perubahan kurikulum di Lembaga Islam harus diorientasikan pada kompetensi yaitu knowledge (pengetahuan), skill (keterampilan atau kemahiran), ability (memiliki kemampuan tertentu), sosial-kultural, dan spritual ilahiyah.

Prinsip hakekat Kelembagaan Islam yang digunakan Hasim Amir, yang mengemukakan bahwa Kelembagaan Islam adalah Lembaga yang idealistik, yakni suatu lembaga yang integralistik, humanistik, pragmatik dan berakar pada budaya kuat. Tawaran ini, dikutip A. Malik Fadjar, dapat digunakan sebagai konsep Keelmbagaan Islam dalam menghadapi perubahan masyarakat Indonesia, yaitu:

Pertama, lembaga integralistik, merupakan model lembaga yang diorientasikan pada komponen-komponen kehidupan yang meliputi: lembaga yang berorientasi pada Rabbaniyah (ketuhanan), insaniyah (kemanusiaan) dan alamiyah (alam pada umumnya), sebagai suatu yang integralistik bagi perwujudan kehidupan yang baik dan untuk mewujudkan rahmatan lil 'alamin, serta lembaga Islam yang menganggap manusia sebagai sebuah pribadi intelektual, perasaan, individual-sosial 
dan jasmani-rohani,. Kelembagaan integralistik diharapkan dapat menghasilkan manusia (peserta didik) yang memiliki integritas tinggi, yang dapat bersyukur dan menyatu dengan kehendak Tuhannya, menyatu dengan dirinya sendiri sehingga tidak memiliki kepribadian tidak utuh atau kepribadian mendua, menyatu dengan masyarakat sehingga dapat menghilangkan disintegrasi sosial, dan dapat menyatu dengan alam sehingga tidak membuat kerusakan, tetapi menjaga, memelihara dan memberdayakan serta mengoptimalkan potensi alam sesuai kebutuhan manusia.

Kedua, kelembagaan yang humanistik, merupakan model lembaga yang berorientasi dan memandang manusia sebagai manusia (humanisasi), yakni makhluk ciptaan Tuhan dengan fitrahnya. Maka manusia sebagai makhluk hidup, ia harus mampu mempertahankan, melangsungkan, dan mengembangkan hidupnya. Maka posisi kelembagaan Islam dapat membangun proses humanisasi, artinya menghargai hak-hak asasi manusia, seperti hak untuk menyuarakan kebenaran, hak untuk berbuat kasih sayang, hak untuk berlaku dan diperlakukan dengan adil, dan lain sebagainya. Manusia "yang manusiawi" yang dihasilkan oleh lembaga Islam yang humanistik diharapkan dapat membentuk dan mengembangkan manusia berasa, berpikir, berkemauan dan bertindak sesuai dengan nilai-nilai luhur kemanusiaan yang dapat mengganti sifat individualistik, egoistik, egosentrik dengan sifat menghormati dan dihormati, sifat menghargai hak-hak asasi manusia, sifat saling menolong, sifat ingin memberi dan menerima, sifat ingin mencari kesamaan, sifat kasih sayang kepada sesama manusia, sifat menghargai perbedaan dan sebagainya.

Ketiga, kelembagaan pragmatik adalah suatu lembaga yang memandang manusia sebagai makhluk hidup yang selalu membutuhkan sesuatu untuk mempertahankan, melangsungkan, dan mengembangkan hidupnya baik bersifat jasmani maupun rohani, seperti merasa, berpikir, keadilan, aktualisasi diri, dan kebutuhan spritual ilahiyah. Dengan 
demikian, model lembaga Islam dengan pendekatan pragmatik diharapkan dapat mencetak manusia pragmatik yang sadar akan kebutuhan-kebutuhan hidupnya, dapat membedakan manusia dari kondisi dan situasi yang tidak manusiawi, dan peka terhadap masalah-masalah sosial kemanusiaan.

Keempat, lembaga Islam yang berakar pada budaya, yaitu lembaga Islam yang tidak meninggalkan akar-akar sejarah, baik sejarah kemanusiaan pada umumnya maupun sejarah kebudayaan suatu bangsa, kelompok etnis, atau suatu masyarakat tertentu. Maka dengan model lembaga Islam yang berakar pada budaya, diharapkan dapat membentuk manusia yang mempunyai kepribadian, percaya pada diri sendiri, harga diri, dan membangun peradaban berdasarkan budaya sendiri yang akan menjadi warisan monumental dari nenek moyangnya dan bukan budaya bangsa lain. Tetapi dalam hal ini bukan berarti kita menjadi orang yang anti kemodernan, reformasi, perubahan, dan menolak begitu saja arus transformasi budaya dari luar tanpa melakukan seleksi dan alasan yang kuat.

\section{Manajemen dalam Pondok Pesantren}

Kelembagaan Islam pertama didirikan di Indonesia adalah dalam bentuk pesantren. Dengan karaktemya yang khas "religius oriented", pesantren telah mampu meletakkan dasar-dasar lembaga keagamaan yang kuat. Para santri tidak hanya dibekali pemahaman tentang ajaran Islam tetapi juga kemampuan untuk mempertahankan dan menyebarkan Islam.

Berikut ini hendak dibahas penjabaran fungsi-fungsi manajemen pada Kelembagaan Islam pondok pesantren. (1) Perencanaan, yaitu perencanaan ialah rancangan kegiatan yang akan dilaksanakan di masa yang akan datang untuk mencapai tujuan. Perencanaan mengandung unsur-unsur sejumlah kegiatan yang ditetapkan sebelumnya, adanya proses, ada hasil yang ingin dicapai, dan menyangkut masa depan dalam waktu tertentu (Usman, 2011:65-66). Bagi Pondok Pesantren, rencana jangka panjang sangat besar manfaatnya, bekerja berdasarkan 
rencana dan cita-cita yang ideal-rasional, dampak terhadap penggarapan perlengkapan fisik (sarana prasarana) dan nonfisik (pendidikan), niscaya akan jauh lebih baik, terarah dan tepat sasaran daripada bekerja asal jalan, tanpa arah dan cita-cita. Apabila rencana tidak ada, organisasi mungkin akan jalan di tempat, salah arah atau bahkan mudah terbawa arus. Penjabaran perencanaan dalam kelembagaan Islam pondok pesantren, seyogyanya berangkat dari visi, misi, dan tujuan. Untuk merumuskan program menengah dan jangka panjang sebaiknya secara luas mengundang para ulama, pakar, pendukung, alumni yang kompeten, dan tokoh-tokoh masyarakat, di samping pimpinan dan pengurus pondok pesantren itu sendiri, untuk bersama-sama menyusun rencana strategis (Renstra). Suatu bentuk program jangka menengah atau panjang lebih matang yang penyusunannya melibatkan semua pihak, sehingga pondok pesantren beserta program jangka menengah dan panjangnya mendapat dukungan luas. Kemudian hasil RENSTRA itu dijadikan acuan dalam penyusunan program-program tahunan. (2) Pengorganisasian (Organizing), yaitu organisasi adalah sekelompok orang yang bekerjasama untuk mencapai tujuan tertentu. Organisasi itu merupakan "wadah" bagi mereka (Manullang, 2008:59). Tujuan dan manfaat organisasi: mengatasi keterbatasan kemampuan individu-individu, pencapaian tujuan yang akan lebih efektif dan efisien bila diusahakan secara bersama, pembagian tugas sesuai bidang, kepentingan bersama yang kompleks, cita-cita besar, mewadahi berbagai potensi, memperoleh penghargaan dan keuntungan, spesialisasi, teknologi, tatakrama berdasarkan potensi bersama, dan menambah pergaulan; dan memanfaatkan waktu untuk kepentingan yang jauh lebih besar. Penempatan dan pemberdayaan sumber daya manusia dalam organisasi (staffing), intinya mengusahakan secara sungguhsungguh penerapan the right man on the right place serta pembinaan dan pengembangan melalui penataran, pengarahan, atau diklat, dan melalui penghargaan dan sanksi seperti promosi, mutasi, rolling dan sebagainya. Masalah pembinaan dan pengembangan sumber daya manusia berupa 
promosi, mutasi dan sejenisnya dalam dinamika kepengurusan pondok pesantren sebagai lembaga pendidikan swasta, tentunya diperlukan modifikasi dan penyesuaian. (3) Pengarahan dan penggerakan (Directing, Actuating) yaitu pengarahan (directing, leading) identik dengan motivating, actualizing, action, moderating, penggerakan. Organisasi pada umumnya digerakkan dengan rapat dan non rapat. Obyek utamanya adalah pelaksanan program, meski tidak terbatas hanya program bila ada sesuatu yang mendesak dan perlu dimusyawarahkan. Dalam pondok pesantren yang menerapkan manajemen, pada dasarnya semua cara penggerakan tersebut di atas dapat diaplikasikan, tentunya dengan berbagai kemungkinan penyesuaian karena pertimbangan kultural. (4) Pengontrolan (Controlling), obyek pengawasan dan pengontrolan meliputi semua aktivitas yang dilaksanakan oleh manajer dalam upaya memastikan bahwa hasil aktual sesuai dengan hasil yang direncanakan (Mac Kanzie R.A, 1969:7). Pelaksanaan controlling ini ada yang dilaksanakan secara formal dalam laporan-laporan rutin seperti laporan triwulan, caturwulan, semester atau laporan pertanggungjawaban (LPJ) setiap akhir tahun. Fokus utamanya pada pelaksanan dan penjabaran program dan anggaran. Ada pula yang bersifat nonformal di luar rapat dan di luar program dan anggaran bila dipandang perlu dan proporsional. Bahkan dimungkinkan adanya pengontrolan bersifat rahasia.

\section{Manajer yang Ideal dan Kompetensi yang Diharapkan}

Manajer yang ideal memiliki ciri-ciri: (1) visioner, yaitu: memiliki visi yang ideal namun jelas, memiliki rencana; di dukung oleh filosofi yang ideal namun bisa dipahami, serta memiliki visi yang jauh ke depan, (2) patuh terhadap kebijakan, aturan dan prosedur suatu bentuk keteladanan, (3) mampu merencanakan dan mengorganisasikan, (4) mampu memecahkan masalah dan mengambil keputusan cerdas, adil, bijaksana, (5) mampu bekerjasama dengan tim dan berkolaborasi, berprinsip juga fleksibel, (6) bersikap terbuka, komunikatif secara lisan, 
tertulis, mempersuasi dan mampu mempengaruhi; cerdas emosional dan intelektual, (7) mampu membimbing dan mengembangkan orang lain dan (8) berorientasi pada hasil, tidak hanya ahli teori, tapi mementingkan karya nyata dan bukti. Delapan kriteria manajer tersebut dikemukakan oleh Kapusdiklat Tenaga Teknis Pendidikan dan Keagamaan Kementerian Agama R.I. dalam suatu acara pembukaan serangkaian penulisan modul yang diikuti oleh widyaiswara dan sejumlah dosen UIN pada tahun 2012.

Pondok pesantren biasanya mempunyai karakteristik tersendiri, antara lain dilatarbelakangi oleh budaya patuh terhadap Kyai yang memiliki otoritas sangat besar dalam pondok pesantren. Hal itu juga tergantung pada "sistem pemerintahan" pondok-pondok pesantren yang berjumlah ribuan dan masing-masing memiliki tingkat budaya kepatuhan terhadap Kyai yang berbeda-beda. Masing-masing pondok pesantren juga memiliki beraneka ragam dalam sistem pendidikannya. Ciri-ciri manajer yang ideal, dapat memberikan manfaat yang besar bagi pondok pesantren. Sebagian ciri-ciri itu juga sudah nampak pada sistem kepemimpinan sejumlah besar pondok pesantren dengan tingkat heterogenitas variasi tinggi.

\section{Penerapan Manajemen bagi Pondok Pesantren}

Manajemen yang pada awalnya diterapkan dalam dunia bisnis, sekarang banyak diterapkan dalam kelembagaan Islam, sebagai ilmu tata kelola, pasti sangat banyak yang bisa dimanfaatkan oleh berbagai aktivitas pengelolaan organisasional, termasuk oleh organisasi atau kelembagaan Islam yaitu pondok pesantren. Lembaga Islam termasuk pondok pesantren memiliki visi misi keagamaan disamping mencari relevansi seperti lembaga Islam lainnya. Misalnya terkait dengan model manajemen yang dipandang paling ideal, yaitu Total Quality Management (TQM) (Baharuddin, 2010:35). Salah satu target utama TQM yaitu memuaskan pelanggan dan kepentingannya diutamakan mengalahkan target-target yang lain. Apabila TQM diterapkan sepenuhnya dalam kelembagaan agama seperti pondok pesantren, visi-misi keagamaan pondok pesantren 
bisa disubordinasikan atau mungkin bila perlu dikorbankan. Salah satu kritik terhadap TQM, yaitu penggunaan istilah "pelanggan" (customer), istilah ini bercorak komersial yang bila berlebihan dalam lembaga Islam dapat mengalahkan visi misi lembaga agama, tentunya tidak tepat diaplikasikan dalam kelembagaan Islam.

\section{Simpulan}

Ilmu manajemen sebagai ilmu tata kelola yang obyektif dan ilmiah, sangat baik diterapkan dalam dunia kelembagaan Islam termasuk madrasah dan pondok pesantren. Meski demikian, mungkin terdapat teori-teori tertentu yang harus dikritisi dan diseleksi. Konsep sistem kelembagaan Islam terbaik, yaitu sistem pondok pesantren bermadrasah yang lebih ideal. Pada hakikatnya timbulnya madrasah dan pesantren di dunia Islam merupakan usaha pengembangan dan penyempurnaan kegiatan proses pembelajaran dalam upaya untuk menampung pertumbuhan dan perkembangan ilmu pengetahuan.

Madrasah sebagai awal dari ujung tombak terdepan dalam pelaksanaan proses pendidikan Islam, selain itu sebagailembaga Islam awal yang tumbuh dan berkembang dari tradisi lembaga agama dalam masyarakat, memiliki arti penting sehingga keberadaannya terus diperjuangkan.

Kelembagaan Islam harus senantiasa bertitik tolak dari rumusan di atas sehingga output dari lembaga ini mampu bersaing dengan lembaga pendidikan lain. Beberapa lembaga Islam ini tengah berproses me-manage komponen Kelembagaan Islam. Sayangnya jumlah lembaga Islam yang sedang berbenah tidak berbanding lurus dengan banyaknya kelembagaan Islam yang belum bergerak untuk melakukan pembenahan manajemen secara serius. Kendala inilah yang kerap mewarnai citra kelembagaan Islam yang masih terpuruk. Respon yang terbaik adalah melakukan pembenahan, kajian, dan strategi manajerial maupun leadershipnya. Perubahan yang dimaksud adalah merevisi strategi-strategi konvensional 
menjadi strategi-strategi transformatif, di mana strategi ini akan memberdayakan potensi-potensi yang dimiliki oleh kelembagaan Islam menjadi kekuatan yang handal dalam mengawal, mengantarkan, dan mewujudkan keberhasilan dan kemajuan kelembagaan Islam, baik secara fisik maupun kualitasnya.

\section{Daftar Pustaka}

Ahmadiansah, Reza. "Motivasi Kerja dan Kepuasan Kerja Terhadap Kinerja Guru SMK Muhammadiyah Salatiga" Inject Vol 1 No 2 Desember 2016

Ali, Hamdani. 1993. Filsafat Pendidikan. Yogyakarta: Kota Kembang Arifin, M. 1995. Kapita Selekta Pendidikan Islam dan Umum. Jakarta: Bumi Aksara

Baharuddin. 2010. Menejemen pendidikan islam, Malang: UIN Maliki Darmuin. 1998. Prospek Pendidikan Islam di Indonesia: Suatu Telaah terhadap Pesantren dan Madrasah. Dalam Chabib Thoha dan Abdul Muth'i. PBM-PAI di Sekolah: Eksistensi dan Proses Belajar Mengajar Pendidikan Agama Islam. Yogyakarta: Pustaka Pelajar bekerja sarna dengan Fakultas Tarbiyah 1AIN Walisongo Semarang

Delors, Jacques. t.th. Education the Necessary Utopia, in Learning the Treasure Within. New York: UNESCO Publishing

Departemen Agama. 1991. Himpunan Peraturan Perundang-undangan Tentang Sistem Pendidikan Nasional, Jakarta: Ditjenbinbaga Islam Djaelani, Kadir H. A. 2001. Konsepsi Pendidikan Agama Islam dalam Era Globalisasi, Jakarta: Putra Harapan

Fadjar, M.A. 1998. Madrasah dan Tantangan Modernitas. Bandung: Mizan Handoko, Hani.T. 2003. Manajemen. Yogyakarta: UGM

Hasibuan, Malayu S.P. 2001. Manajemen Dasar, Pengertian dan masalah. Jakarta: Bumi Aksara

Kanzie, Mac R.A. 1969. The Management Process in 3-D. Harvard: Bussines Review 
Makdisi, George. 1992. Typology of Institutions of Learning. Issa J. Boulatta. An Antology Studies. Montreal: McGill Indonesia IAIN Development Project

Maksum. 1999. Madrasah; Sejarah dan Perkembangannya. Jakarta: Logos

Manullang, M \& Amnullang Marihot. Amh. 2008. Manajemen Personalia.

Yogyakarta: Gajah Mada University Press

Stanton, Michael Charles. 1994. Pendidikan Tinggi dalam Islam. Terj. Afandi dan Hasan Asari. Jakarta: Logos

Aly, Hery Noer. 1999. Ilmu Pendidikan Islam. Jakarta: Logos

Purwanto, Ngalim. 2010. Administrasi dan Supervisi Pendidikan. Bandung: Remaja Rosdakarya

Schuller, R.S. "Repositioning The Human Resources Function: Transforming or Demise”. Academy Management Executive". Vol. 4, No. 3 Tahun 1990

Stoner J.A.F. and Freeman R.E. 2000. Management. New Jersey: PenticeHall International Editions

Sternbrink. K.A. 1986. Pesantren, Madrasah dan Sekolah. Jakarta: LP3ES

Sudarjito. 2003. Rekonstruksi Kurikulum untuk Menunjang Berfungsinya

Lembaga Pendidikan sebagai Pusat Pembudayaan Kemampuan, Nilai dan Sikap. Dalam Ronisef, Syafnir dkk. (Eds), Mengurai Benang Kusut Pendidikan; Gagasan Para Pakar Pendidikan. Jakarta: Tranformasi UNJ

Suroyo. "Perbagai Persoalan Pendidikan; Pendidikan Nasional dan Pendidikan Islam di Indonesia, Jurnal Pendidikan Islam, Kajian tentang Konsepo Pendidikan Islam, Problem dan Prospeknya”. Vol. 1 tahun 1991

Suryadi, Ace dan H.A.R Tilaar. 1993. Analisis kebijakan pendidikan suatu pengantar. Bandung: PT remaja Rosdakarya

Tadjab. 2000. Perbandingan Pendidikan. Surabaya: Karya Abditama Usman, Husaini. 2008. Manajemen Teori Praktik \& Riset Pendidikan. Jakarta:Bumi Aksara, Edisi Kedua 
INJECT (Interdisciplinary Journal of Communication), Vol.3, No.2, Des. 2018: h. 231-252

2010. Manajemen: Teori, Praktik dan Riset Pendidikan. Jakarta: Bumi Aksara

. 2011. Manajemen, Teori, Praktik Dan Riset Pendidikan. Jakarta: PT. Bumi Aksara

Zulkarnain. 2008. Transformasi Nilai-nilai Pendidikan Islam. Yogyakarta: Pustaka Pelajar 